Original Research Paper

\title{
The Effect of Plant Growth Regulators (PGRs) on Efficient Regeneration of 12 Recalcitrant Indica Rice (Oryza Sativa L.) Genotypes
}

\author{
Md. Nazmul Hasan, Fahmid H. Bhuiyan, Hammadul Hoque, Nurnabi Azad Jewel, \\ Md. Ashrafuzzaman and Shamsul H. Prodhan* \\ Department of Genetic Engineering and Biotechnology, Plant Genetic Engineering Laboratory, \\ Shahjalal University of Science and Technology, Sylhet-3114, Bangladesh
}

\author{
Article history \\ Received: 22-01-2021 \\ Revised: $15-03-2021$ \\ Accepted: 17-03-2021 \\ Corresponding Author: \\ Shamsul H. Prodhan \\ Department of Genetic \\ Engineering and \\ Biotechnology, Plant Genetic \\ Engineering Laboratory, \\ Shahjalal University of Science \\ and Technology, Sylhet-3114, \\ Bangladesh \\ Email: shamsulhp-btc@sust.edu
}

\begin{abstract}
Biotechnological approaches provide an efficient and expeditious system for developing agronomic features of rice at the cellular and molecular level compared to traditional breeding methods. The in-vitro regeneration method optimization of recalcitrant indica rice genotypes is a critical step for the biotechnological approaches for further development as the optimum concentrations of Plant Growth Regulators (PGRs) for in-vitro regeneration vary from genotype to genotype. Here, 12 important rice genotypes, including local cultivars and varieties, were collected from different regions of Bangladesh and evaluated for their in-vitro regeneration potentiality. Mature dehusked sterilized rice seeds were inoculated on different basal media (MS, N6, B5) supplemented with different concentrations of 2,4-Dichlorophenoxyaceitic acid (2,4-D) for callus induction. Induced calli were transferred to N6 media supplemented with different combinations of 6-Benzylaminopurine (BA) and 1Napthaleneacetic acid (NAA) for shoot induction. Regenerated shoots were rooted on half-strength MS media without supplementation of any hormones. Treatments of different concentrations and combinations of plant growth regulators showed varying results. Maximum callus induction frequencies were observed with 2.5-3.0 mg/l supplementation of 2,4-D on N6 media where Saat, Jamaibabu and Nimikhanai showed the highest callus induction frequencies $(84.44 \% ; 78.89$ and $80 \%$ respectively) and maximum shoot initiation was observed at $2.5 \mathrm{mg} / \mathrm{l} \mathrm{BA}+1.0 \mathrm{mg} / \mathrm{l} \mathrm{NAA}$ and $3.0 \mathrm{mg} / \mathrm{l}$ 6-BA $+1.5 \mathrm{mg} / 1$ NAA supplemented media where rice genotypes BRRI Dhan71, Nayapaijam, Nimikhanai and BRRI Dhan28 showed the highest shoot induction frequencies-86.67, 85.00, 86.67 and $88.33 \%$ respectively. Nearly all of the induced shoots showed root formation on half-strength MS media. This study demonstrates variations in regeneration response of the rice genotypes where cultivars Jamaibabu, Nayapaijam and Nimikhanai showed the highest in-vitro regeneration potential.
\end{abstract}

Keywords: Indica Rice, PGRs, Callus, Regeneration

\section{Introduction}

Rice is a semi-aquatic grass belonging to the Poaceae family, grown mostly in tropical and sub-tropical regions and more than half of the world's population take rice as a staple food (Gnanamanickam, 2009). Out of 23 species, only two species (Oryza sativa and Oryzaglaberrima) are well known for their commercial value, while the two subspecies Oryza sativaindica and Oryza sativa japonica, are widely cultivated in Asia (Linares, 2002). Bangladesh is a major rice-producing country holding the fourth position in rice production throughout the world (Wright, 2020). Rice production in Bangladesh is increasing day by day, and Bangladesh is now nearly self-dependent in rice production. Aman, Aus and Boro are three major rice groups cultivated in three overlapping seasons, and each rice group has numerous rice germplasms with distinct agro-ecological and climatic niches. According to 
Bangladesh Rice Research Institute (BRRI), approximately 8200 germplasms have been collected and conserved by the BRRI genebank (Islam et al., 2018). Bangladesh's population is projected to reach 230-250 million by 2050 (UNDP), and the global food demand will increase by $87 \%$ by the year 2050 (Kromdijk and Long, 2016). But according to many reports, the nation is losing $1 \%$ of agricultural land every year, and agriculture is facing several abiotic and biotic constraints like flash flood, drought, salinity, water logging due to flood, cold and bacterial, viral, fungal diseases (Rasheed et al., 2020; Mazumder et al., 2020). To combat the future situations, it will need the replacement of current rice varieties with modern rice varieties having improved agro-ecological and climatic features. With the advancement of science, modern techniques like marker-assisted breeding, somaclonal variation, genetic engineering and CRISPR-Cas9 could improve rice to overcome these problems (Romero and Gatica-Arias, 2019). However, a suitable regeneration system of rice callus derived from mature seeds is a prerequisite for almost every modern technique (somaclonal variation, Agrobacterium-mediated transformation (Hasan et al., 2019a), CRISPR-Cas9 mediated genome editing) of rice improvement (Miyao et al., 2012; Hiei and Komari, 2008; Mazumdar et al., 2016). To date, the development of an effective and robust regeneration system of rice has been limited to only a handful of rice varieties and cultivars, while the mature seed-derived callus regeneration of many agro-economically important rice cultivars have not yet been studied (Paul and Roychoudhury, 2019). Successful tissue culture depends on several factors like the media, explant type, growth regulators and culture conditions, and these factors vary with genotype (Ngomuo et al., 2013; Pasqualetto, 1990; Hasan et al., 2019b). Thus, it is very important to select the best media and evaluate the performance of rice genotype for genetic improvement using modern techniques. Here, we collected six partially salt-tolerant rice genotypes (mostly cultivated in the salinity affected areas of Bangladesh) from local farmers of Satkhira, Khulna and Bagerhat regions and Bangladesh Rice Research Institute (BRRI) and four partially submergence tolerant (mostly cultivated in haor areas of Bangladesh) rice genotypes from local farmers of Sunamganj and Moulvibazar regions. Salt and submergence stresses are the severe problem in Bangladesh for rice production. Scientists are hardly trying to develop salt and submergence tolerant rice through breeding and transgenic approaches. Therefore, the collected rice genotypes were subjected to in-vitro regeneration from mature seed-derived callus as well as comparative analysis with two wellstudied rice genotype BRRI Dhan28 and BRRI Dhan29 were done (Chakraborty et al., 2017; Mukherjee et al., 2015). Several investigations on in-vitro regeneration of rice have been conducted, but most of the studies were limited to one or two popular rice variety as well as one basal medium. Here, we performed the comparative analysis of the in-vitro regeneration potentiality of the selected rice genotype and pointed out the best basal media as well as appropriate hormonal concentrations and combinations for in-vitro regeneration protocol. Overall findings and experiment details are presented in this article in materials and methods, results and discussion sections and finally summarized in the conclusion section. Data found in this study would help the researchers for further investigation of in-vitro regeneration of indica rice as well as genetic improvement of rice using CRISPRCas9 mediated genome editing and Agrobacteriummediated transformation.

\section{Materials and Methods}

\section{Plant Materials}

For developing an efficient in-vitro regeneration system, six partially salt-tolerant indica rice genotypes, namely Saat, Talmugur, Jamaibabu, Casrail, BRRI Dhan76, BRRI Dhan71 and four partially submergence tolerant indica rice genotypes, namely Jota Balam, Naya Paijam, Nimi Khanai, BRRI Dhan52 as well as two well-studied rice varieties BRRI Dhan28 and BRRI Dhan29 were selected in this laboratory experiment. The partially salt-tolerant rice genotypes were collected from Satkira, Khulna and Bagerhat regions of Bangladesh. The partial submergence tolerant local rice genotypes were collected from haor areas of Bangladesh, and the BRRI Dhan28 and BRRI Dhan29 were collected from Bangladesh Rice Research Institute (BRRI). The characteristics of rice genotypes were examined and confirmed by aScientific Officer (SO) of the regional station of BRRI, Satkhira.

\section{Explant Sterilization}

The healthy mature seeds were selected as explant in this experiment. Firstly, the rice seeds were washed with $2 \%$ sodium hypochlorite and dried on sterilized tissue paper. The rice seeds were then manually dehusked, washed with $70 \%$ ethanol for 2/3 min and ethanol was removed by washing explants with autoclaved distilled water. Subsequently, the explants were further rinsed in $0.1 \%$ $\mathrm{HgCl}_{2}$ solution supplemented with 2/3 drops of Tween 20 for $1 \mathrm{~min}$. Afterwards, the explants were washed five times with sterilized double-distilled water and finally, the explants were dried on sterilized filter paper $(90 \mathrm{~mm})$. 


\section{Callus Induction}

The mature dehusked and sterilized rice seeds of four rice germplasms were inoculated (20-30 seeds per treatment) on the most commonly used nutrient mediumMurashige and Skoog (MS), Chu's N6 and Gamborg's B5 supplemented with different concentrations (based on published literature) of plant growth regulators under dark and light conditions to identify the best basal media and impact of light for callus induction (Phillips and Garda, 2019). Finally, the best basal media (N6) was supplemented different concentrations of 2,4-D $(0,1,1.5,2,2.5,3,3.5,4,5$ $\mathrm{mg} / \mathrm{l})$ for callus induction. N6 media was prepared by supplementing $3 \%$ sucrose, $0.5 \mathrm{~g} / \mathrm{l}$ casamino acid, $0.1 \mathrm{gm} / \mathrm{l} \mathrm{L}$ proline, $0.1 \mathrm{~g} / \mathrm{l}$ myo-inositol, $0.7 \%$ agar and $\mathrm{pH}$ was adjusted to 5.8 6.0. The media were sterilized in an autoclave at $121^{\circ} \mathrm{C}$ temperature and 15 psi pressure for $20 \mathrm{~min}$. Finally, the media was poured into sterilized test tubes and petridishes under the laminar flow hood to avoid contamination and was kept for cooling. The explants were inoculated on culture media under aseptic condition and then incubated in the dark at $25 \pm 2^{\circ} \mathrm{C}$ temperature (Das et al., 2019). After 10 days of incubation, the inoculated explants were brought under light ( 2000 lux) and were kept for another 5 days. The callus induction frequencies were calculated using the following equation (BinteMostafiz and Wagiran, 2018):

$$
\text { Frequency of calli induction }=\frac{\text { Number of seeds forming callus }}{\text { Number of seedsinoculated }} \times 100 \%
$$

\section{Callus Morphology Evaluation}

The callus morphology was evaluated using visual and light microscopic observations. The calli were categorized into embryogenic and non-embryogenic callus. Randomly selected 5 calli from different treatments were fixed with a modifiedFormalin-Acetic-Alcohol (FAA) solution containing 50\% ethanol (v/v), 5\% glycerol (v/v), 5\% acetic acid $(\mathrm{v} / \mathrm{v})$ and $5 \%$ formaldehyde (v/v) for two hours (Nic-Can et al., 2013; Bello et al., 2017). The samples were dehydrated using different grades of ethanol and embedded using paraffin. Then the samples were sectioned into $5 \mu \mathrm{m}$ and evaluated under a light microscope mounting on slides (BinteMostafiz and Wagiran, 2018).

\section{Regeneration}

The calli from different treatments were transferred to regeneration media containing different concentrations $(0.0+0.0,1.0+0.5,1.5+1.0,2.0+1.0,2.5+1.0,3.0+1.5$, $3.5+2.0)$ of BA and NAA. Here, we used only N6 basal medium for regeneration based on the study where N6 media provideda better result than MS and B5 media. The N6 media were prepared by supplementing $3 \%$ sucrose, $0.7 \%$ agar and the $\mathrm{pH}$ value was adjusted to 5.8 6.0. The calli were inoculated on regeneration media under a laminar flow hood to avoid contamination. The inoculated calli were incubated in a culture room,maintaining $16 \mathrm{~h}$ photoperiods at $25 \pm 2^{\circ} \mathrm{C}$ and $\sim 2000$ lux light intensity. The explants were sub-cultured two times with 10-12 days intervals. Finally, after shoot induction, the number of shoots were calculated.

\section{Root Induction}

When the shoots reached $3 / 4 \mathrm{~cm}$ length, the shoots were transferred onto root induction media. The root induction media was prepared using half-strength MS media (Zahara et al., 2017) fortified with $1.5 \%$ sucrose, $0.7 \%$ agar and without supplementation of any hormone. After root induction, the root number and length were calculated using a measuring scale and visual evaluation.

\section{Acclimation of Regenerated Plantlets}

Regenerated plantlets of 12 rice germplasms were transferred in rice field soil containing pots supplemented with organic fertilizer. The plantlets were watered each day. After three days of transplantation, chemical fertilizer urea (3-4 g per pot) was provided. After 3 weeks, the plantlets started tillering. Finally, when the plants matured, the number of tillers and the height of plants were measured.

\section{Statistical Data Analysis}

All the experiments (callusing, shooting and rooting) were conducted randomly ( $\sim 30$ samples per treatment) and repeated three times. The data were analyzed using software MS Office 365 and GraphPad Prism 8.4.3. Means of callus, shoot and root induction frequencies were calculated. Significant differences $(\mathrm{P}<0.05)$ were evaluated using a two-wayAnalysis Of Variance (ANOVA) followed by a Bonferroni post hoc test. Different means were levelled with different characters $(*, a, b, c, d, e, f, g)$ to represent the significant value of the differences.

\section{Results}

\section{Selection of Basal Media}

The randomly selected four rice germplasms (Talmugur, BRRI Dhan71, Jota Balam and BRRI Dhan29) were inoculated on three basal media (MS, Chu's N6 andGabrog's B5) with supplementation of 2.5 and $3.0 \mathrm{mg} / \mathrm{l}$ 2,4-D (Yaqoob et al., 2016; Hasan et al., 2019a). Here, we also evaluated the impact of light on callus induction. The inoculated cultures were incubated equally in light and dark condition. The different basal media showed different callus induction frequencies. Interestingly, in all cases, inoculated explants showed best callusing frequency in dark condition, as well as the explants inoculated in dark condition showed earlier callusing (10-15 days) (Fig. 1A) than the ones under light condition (15-20 days) (Fig. 1B). Among the three different media, Chu's N6 media showed the best callus induction frequency $(90.21 \pm 1.25 \%)$ at $25 \pm 2^{\circ} \mathrm{C}$ temperature in dark condition (supplimentary Table 3 ). 
(Dark condition)

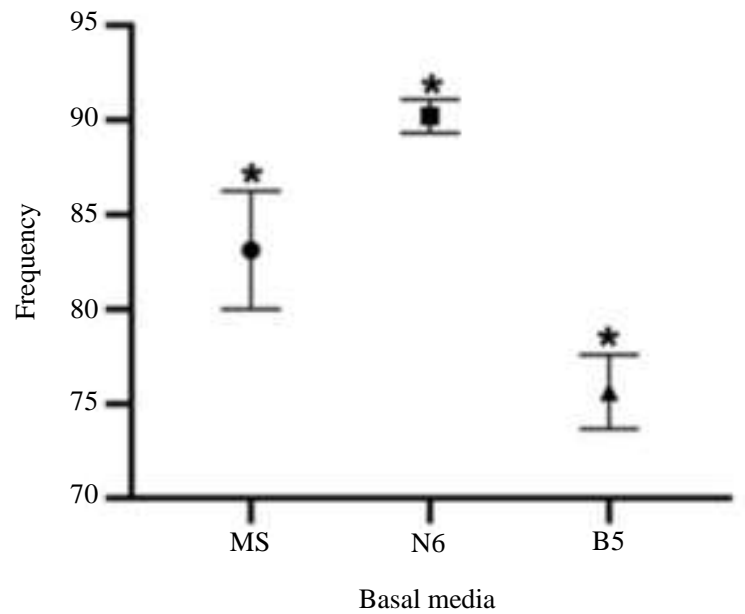

B

(Light condition)

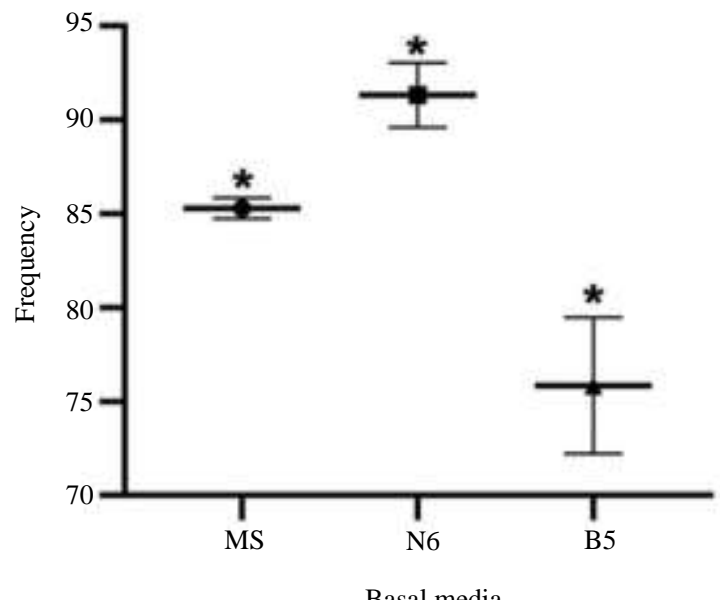

Fig. 1: Callus induction frequencies in Murashige and Skoog (MS), CHU (N6) and Gamborg B5 (B5) medium, (A) inoculated explants were maintained dark condition; (B) inoculated explants were maintained light condition. * Indicate the mean value with a significant difference at $\mathrm{p}<0.05$ according to Bonferroni post hoc test

\section{Callus Induction}

Callus induction mostly depends on the exogenous supply of auxins as well as the type and concentration of auxin. Previous reports and our laboratory study showed that good and reproducible callus induced with the supply of 2,4-D (Sen et al., 2014; Benderradji et al., 2012). In this research, we evaluated the impact of different concentrations of 2,4-D on rice callus induction and developed a suitable regeneration protocol for 12 economically important indica rice genotypes-SAAT, Talmugur, Jamaibabu, Casrail, BRRI Dhan76, BRRI Dhan71, Jota Balam, Naya Paijam, Nimi Khanai, BRRI Dhan52 and compared with well-studied indica rice varieties BRRI Dhan28 and BRRI Dhan29.

Here, the variation in callus induction frequency varied with different treatments of 2,4-D as well as with different genotypes under the same treatment. Among six partially salt-tolerant rice genotypes, two rice genotypes (Talmugur and BRRI Dhan71) showed maximum callusing with supplementation of 2,4-D $2.5 \mathrm{mg} / \mathrm{l}$, where the remaining genotypes (Saat, Jamaibabu, Casrial and BRRI Dhan76) showed highest callusing with $3.0 \mathrm{mg} / \mathrm{l}$ 2,4-D supplementation (Table 1 and Fig. 2a). Rice genotype Saat showed the highest callus induction frequency $(84.44 \%)$ whereas, Talmugur, Jamaibabu, Casrial, BRRI Dhan76, BRRI Dhan71 exhibited 76.67, 78.89, 74.45, 77.78 and $78.89 \%$ induction frequencies (Fig. 2b). On the other hand, partially submergence tolerant rice genotypes showed nearly similar results with the above-mentioned rice genotypes. Here, all the rice genotypes showed maximum callus induction frequencies on the $3.0 \mathrm{mg} / \mathrm{l}$ 2,4-D supplied media except Jotabalam, which showed maximum callusing on $2.5 \mathrm{mg} / \mathrm{l}$ supplied media. (Table 1 and Fig. 2b). There was no callus observed on media where 2,4-D was not supplemented for all cases. Callus induction frequency increased with the increment of 2,4-D concentration up to $3 \mathrm{mg} / \mathrm{l} 2,4-\mathrm{d}$ and then decreased with the increment of 2,4-D. In comparison with BRRI Dhan 28 and BRRI Dhan29, all the rice genotypes showed more callusing potentiality (Table 1). Most of the calli were granular and light yellowish in colour, and some were compact and whitish in colour.

\section{Callus Morphology}

Callus morphology of every rice genotype was evaluated, which showed that all rice genotypes provide embryonic and non-embryonic calli with every callus induction media except control media where 2,4-D was not supplemented. The embryonic calli were compact, globular in shape and whitish to light yellowish in colour. On the other hand, non-embryonic calli were rickety and brownish in colour. Maximum embryonic calli were observed on the 2.5-3.0 mg/l supplemented 2,4-D media. Calli from $3 \mathrm{mg} / 1$ supplemented media were subjected to histological examination. Analysis showed that embryogenic (EM) calli were compact, globular and had tightly packed cells. In contrast, the nonembryogenic (NEM) calli were watery and had loosely held cells (Fig. 3). 


\section{Shoot Induction}

Inducted calli were transferred to shoot induction media supplemented with different combinations of BAP and NAA in Chu's N6 basal media. 30 calli from each genotype wereinoculated for shoot generation having an average size of5 centimetres in radius. After 14-18 days of inoculation, the calli started to become greenish, and 21 days later, the calli started to form shoots. Different treatments showed different frequencies of shoot induction. No shooting was observed in the media where no hormone was supplemented. The shoot induction frequency increased with the increment of the combination of the hormone concentration up to $3.0+1.5 \mathrm{mg} / 1 \mathrm{BA}+\mathrm{NAA}$ and then decreased with the increment of hormonal concentration $(3.5+2.0 \mathrm{mg} / \mathrm{l} \mathrm{BA}+\mathrm{NAA})$ for each rice genotype (Table 2). The maximum shoot induction frequency was observed on the Chu's N6 media supplemented with $2.5+1.5$ and $3.0+1.5 \mathrm{mg} / \mathrm{l}$ (Fig. 4b). Among six partial salt-tolerant rice genotypes, BRRI Dhan71, Jamaibabu and Casrail showed regeneration frequencies-86.67, 83.33 and $80 \%$ respectively on the media supplemented with $2.5+1.0 \mathrm{mg} / \mathrm{l} \mathrm{BA}+\mathrm{NAA}$. Saat, Talmugur, and BRRI Dhan76 were showed the highest shoot induction frequencies $(80,80$ and $81.67 \%$, respectively) in the media supplemented with $3.0+1.5 \mathrm{mg} / \mathrm{l} \mathrm{BA+NAA}$ (Table 2). In the case of partially submergence tolerant rice, all the rice genotypes showed maximum shoot induction frequencies $(80,85$ and $83.33 \%)$ on media supplemented with $2.5+1.0 \mathrm{mg} / \mathrm{l} \mathrm{BA}+\mathrm{NAA}$ except

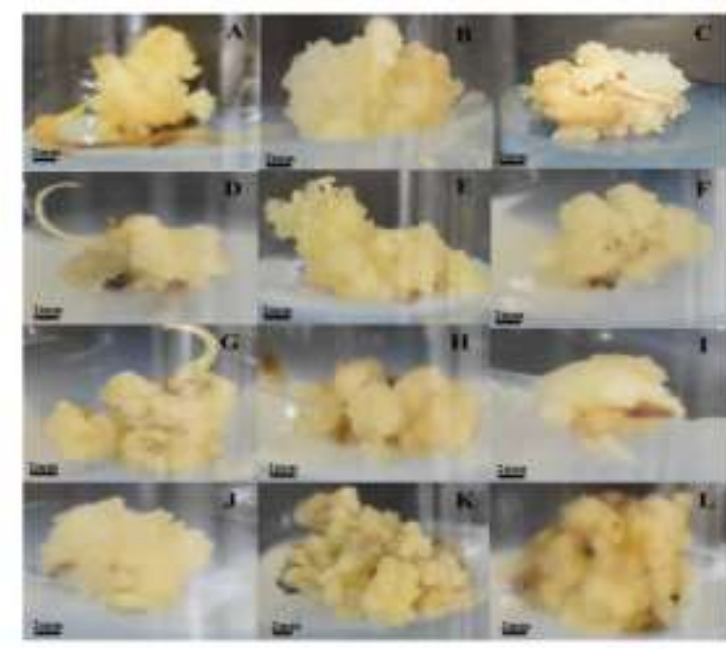

(a)
Nimi Khanai, which showed maximum shoot induction frequency $(86.67 \%)$ in the media supplemented with $3.0+1.5 \mathrm{mg} / 1 \mathrm{BA}+\mathrm{NAA}$. Regeneration of JotaBalam, Noya Paijam and BRRI Dhan52 required less amount of hormones $(2.5+1.0 \mathrm{mg} / \mathrm{l} \mathrm{BA}+\mathrm{NAA})$ to obtain maximum shoot induction compared to BRRI Dhan 28 and BRRI Dhan29 (3.0+1.5 mg/l BA+ NAA). On the other hand, Nimi Khanai showed maximum shoot induction frequency on the media supplemented with $3.0+1.5 \mathrm{mg} / \mathrm{l}$ BA+NAA (Fig. 4a), which was similar to BRRI Dhan28 and BRRI Dhan29 (Table 2). After 4 weeks of inoculation on shoot induction media, the average number of shoots were $8.3 \pm 2.4$ per callus, and the average length of shoots was $20.5 \pm 4.1 \mathrm{~cm}$ (Supplementary Table 1) and then regenerated shoots were transferred to root induction media.

\section{Root Induction}

Plantlets from regeneration media were transferred to root induction media. After 4-5 days, roots started to form on half-strength MS media without supplementation of any hormones (Fig. 5). All the regenerated plantlets transferred to rooting media formed roots. The root number and root length increased with time, and fourteen days later, the root number and length were calculated. Data analysis showed that all the regenerated plantlets inoculated on the rooting media from every rice genotypes (rooting frequency $100 \%$ ) had an average number of $13 \pm 2.3$ roots, and the average length of roots was $2.5 \pm 0.2 \mathrm{~cm}$ (Supplementary Table 1).

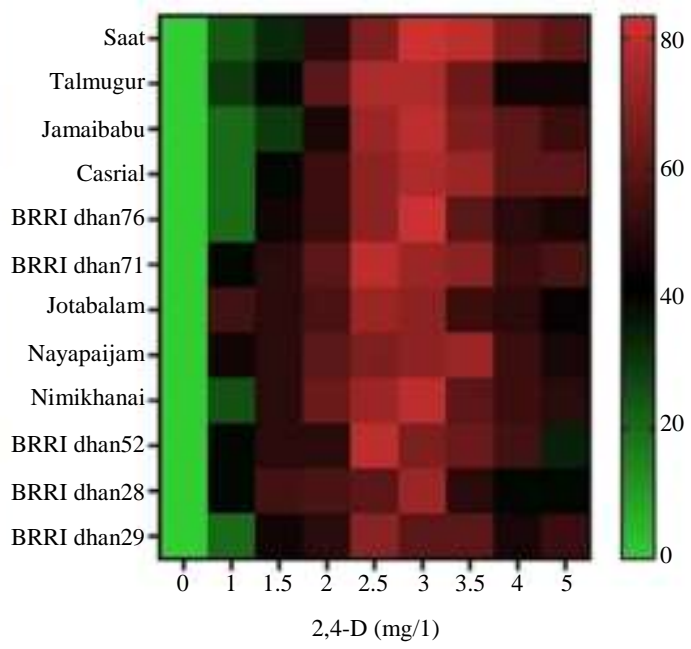

(b)

Fig. 2: (a) The callus morphology of (A) SAAT; (B) Talmugur, (C) Jamaibabu, (D) Casrail, (E) BRRI Dhan76, (F) BRRI Dhan71, (G) Jota Balam, (H) Naya Paijam, (I) Nimi Khanai, (J) BRRI Dhan52, (K) BRRI Dhan28 and(L) BRRI Dhan29 on N6 media supplemented with $3 \mathrm{mg} / \mathrm{L}$ of 2,4-D (Bar $=2 \mathrm{~mm}$ ). (b) Heat map of callus induction frequencies of rice genotypes in N6 Media supplementing different concentrations of $2,4-\mathrm{D}$ 


\section{Acclimatization}

After root induction, the plantlets were removed from the media and were washed with water and transplanted in soil containing pots before keeping them in the culture room at $25 \pm 2{ }^{\circ} \mathrm{C}$ temperature and where $16 \mathrm{~h}$ photoperiod was maintained. Finally, the plantlets were transferred to the natural environment and were watered every day. The survival rates werevery high $(80-90 \%)$ for each rice genotype (Fig. 6). After 4-5 weeks, the plantlets showed a good growth performance and started tillering. The tiller number and plant length were calculated 60 days later. The tiller number and plant height are summarized in Supplementary Table 2 . The average number of tillers was $24.61 \pm 3.55$, and the average plant height was $51.67 \pm 4.9 \mathrm{~cm}$ (Supplementary Table 2 ).
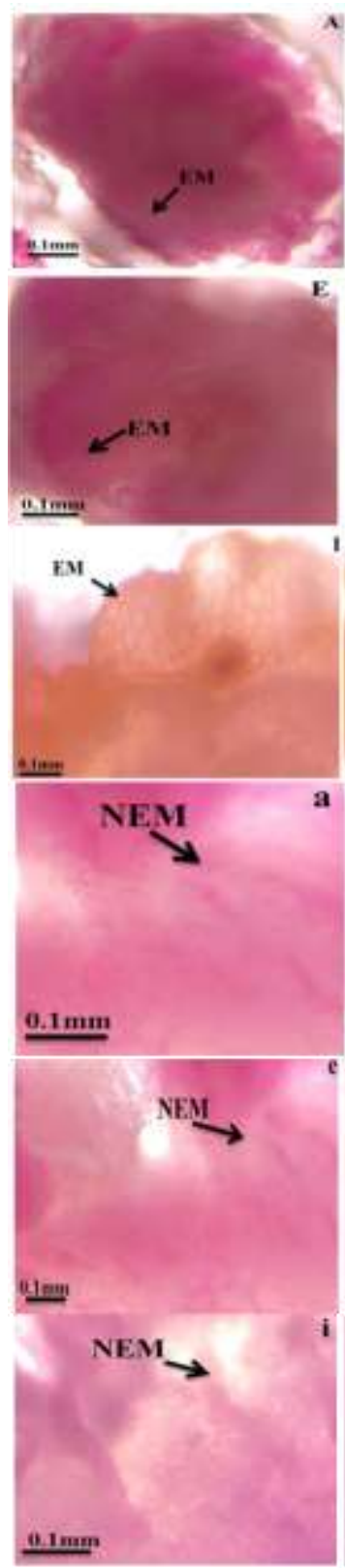
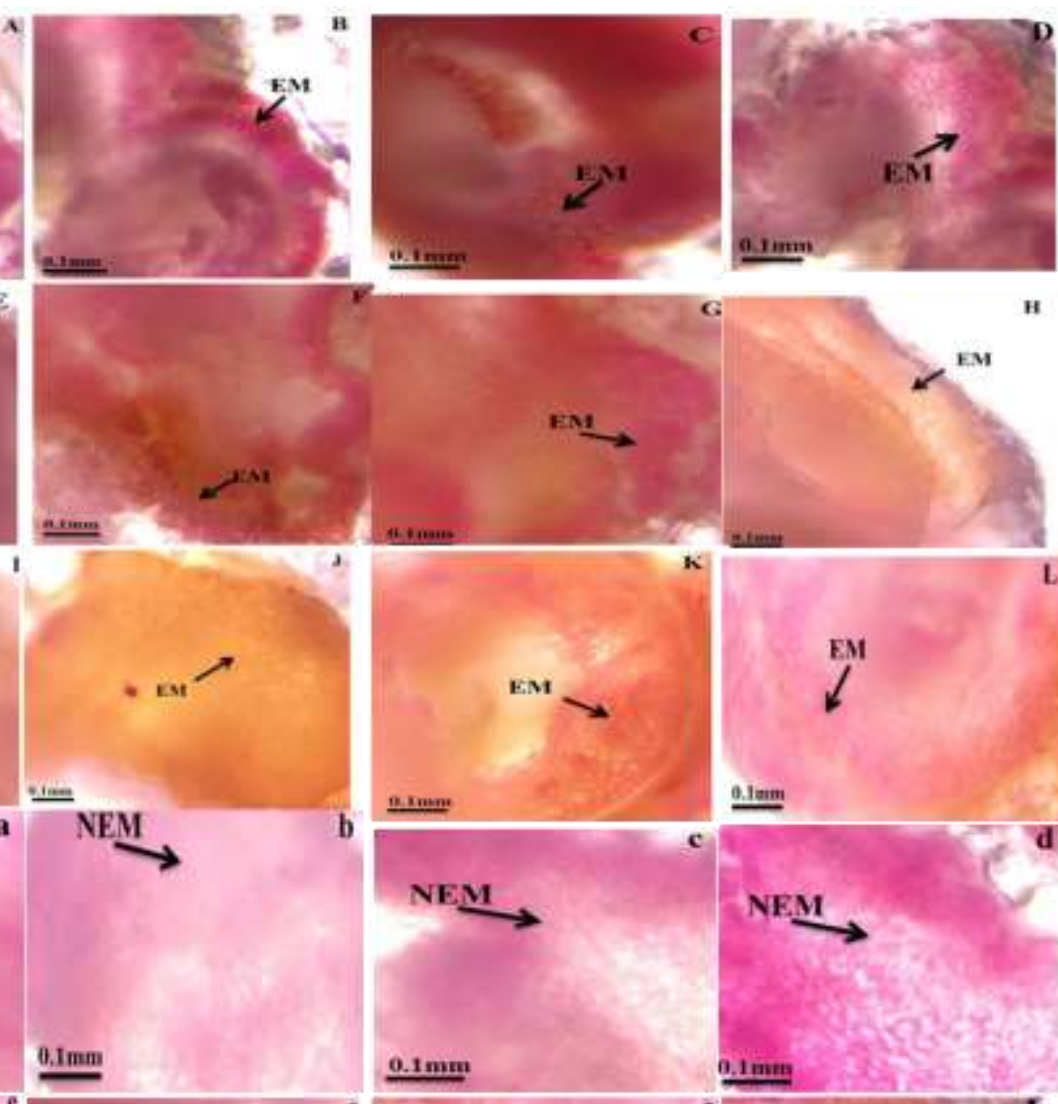

b
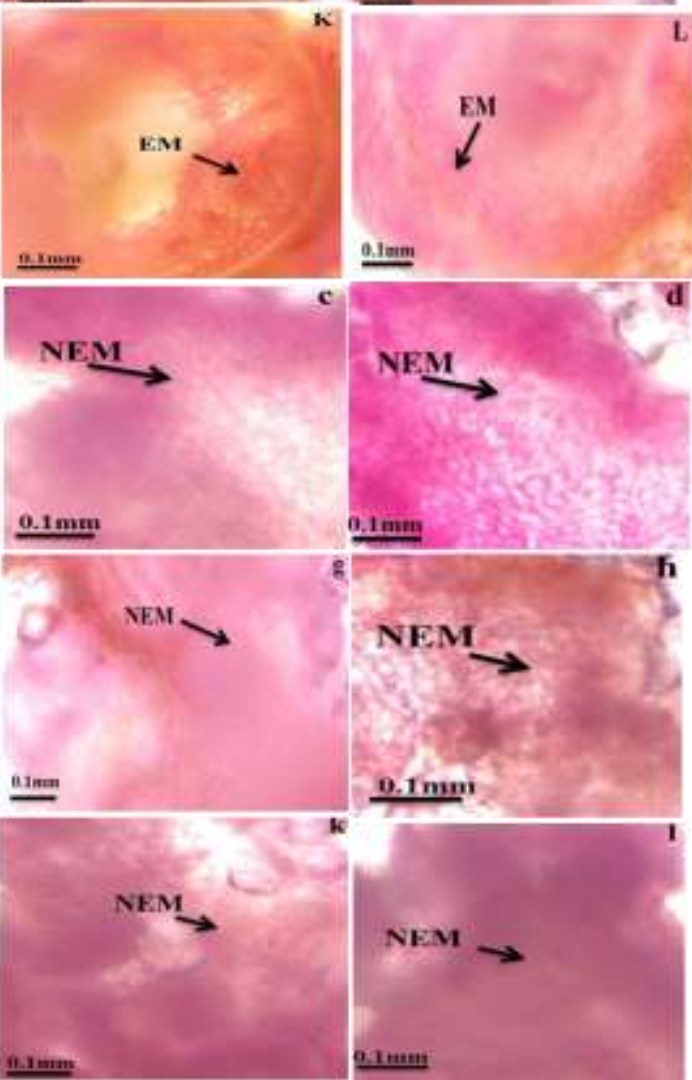

Fig. 3: Histological analysis of calli inducted in the N6 media supplementing3 mg/L 2,4-D for (A,a) SAAT; (B,b) Talmugur, (C,c) Jamaibabu, (D,d) Casrail, (E,e) BRRI Dhan76, (F,f) BRRI Dhan71, (G,g) Jota Balam, (H,h) Naya Paijam, (I,i) Nimi Khanai, $(\mathrm{J}, \mathrm{j})$ BRRI Dhan52, (K,k) BRRI Dhan28 and(L,1) BRRI Dhan29. A-L represent the Embryonic (EM) calli, and a-1 represents the Non-Embryonic (NEM) calli. Magnification $10 \times$ and bar $=0.1 \mathrm{~mm}$ 


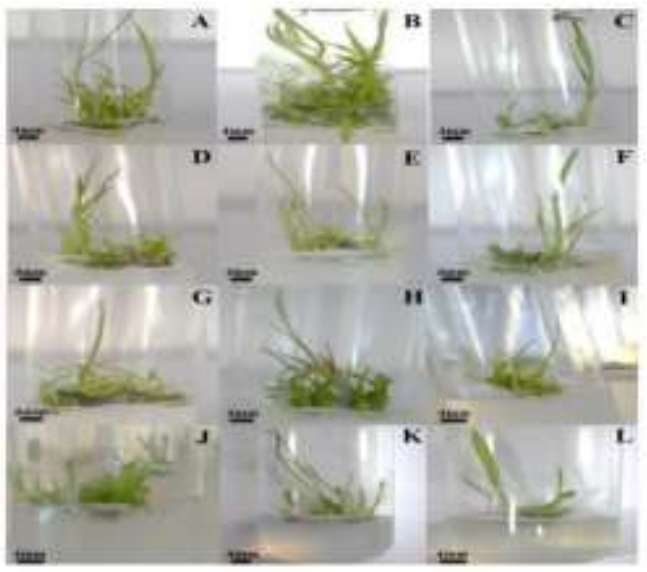

(a)

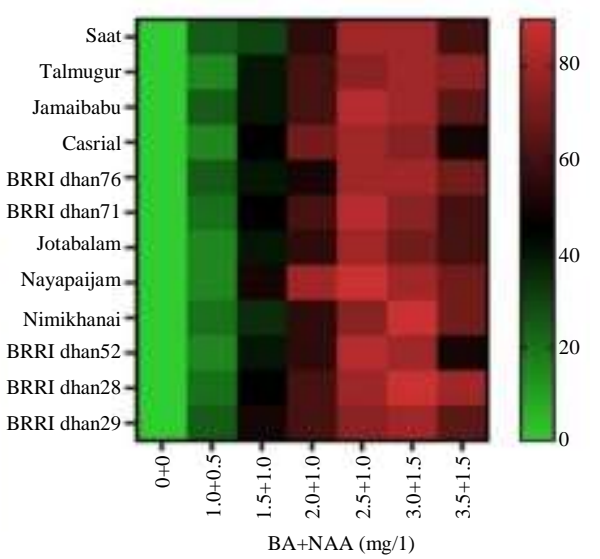

(b)

Fig. 4: (a) Shoot induction of (A) SAAT; (B) Talmugur, (C) Jamaibabu, (D) Casrail, (E) BRRI Dhan76, (F) BRRI Dhan71, (G) Jota Balam, (H) Naya Paijam, (I) Nimi Khanai, (J) BRRI Dhan52, (K) BRRI Dhan28 and (L) BRRI Dhan29 on N6 media supplemented with BA and NAA (Bar $=4 \mathrm{~mm}$ ). (b) Heat map of shoot induction frequencies of rice genotypes in N6 Media supplementing different concentrations of BA+NAA $(\mathrm{mg} / \mathrm{l})$

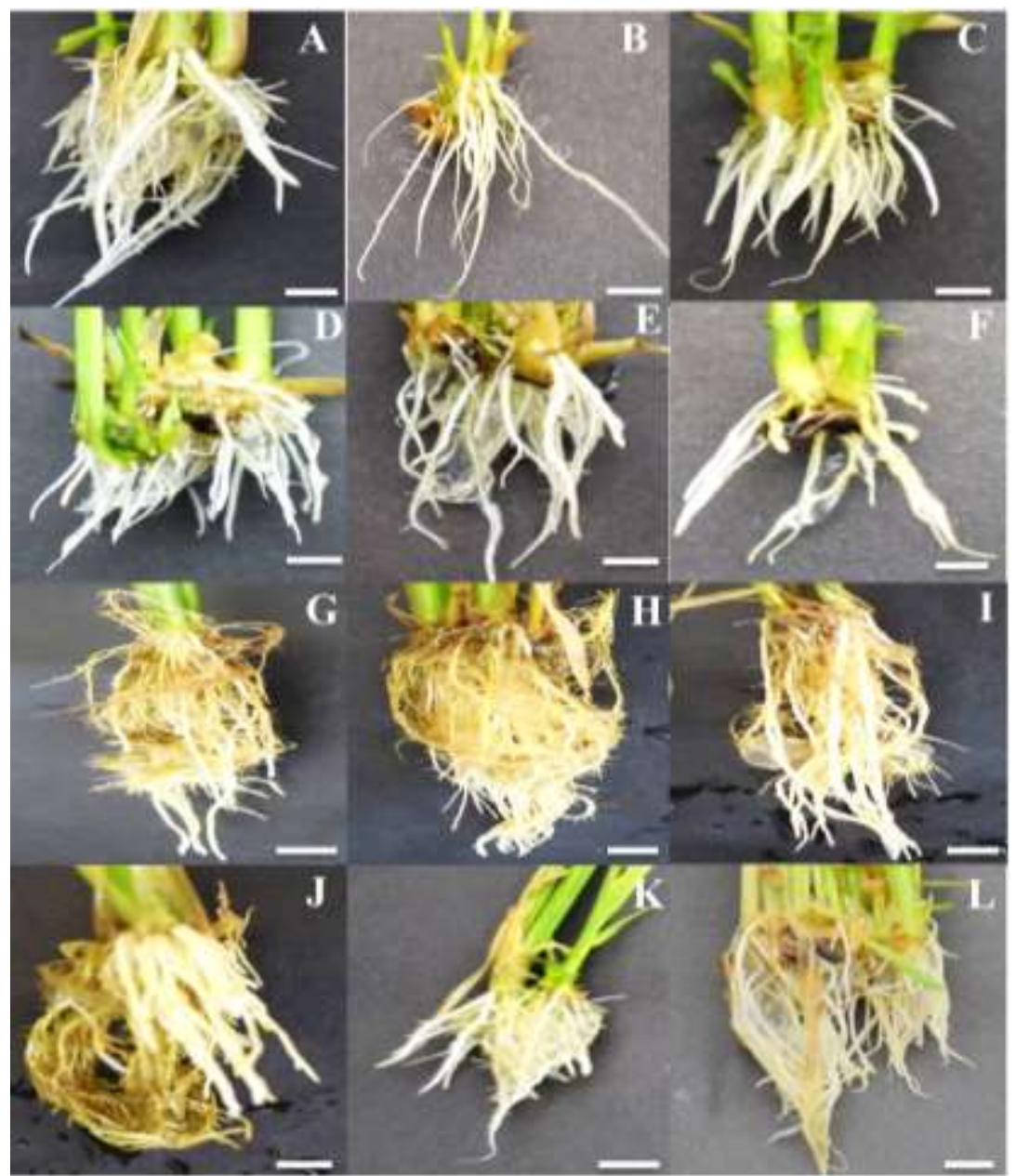

Fig. 5: Root induction of (A) SAAT; (B) Talmugur, (C) Jamaibabu, (D) Casrail, (E) BRRI Dhan76, (F) BRRI Dhan71, (G) Jota Balam, (H) Naya Paijam, (I) Nimi Khanai, (J) BRRI Dhan52, (K) BRRI Dhan28 and (L) BRRI Dhan29 on half-strength MS media $(\mathrm{Bar}=5 \mathrm{~mm})$ 


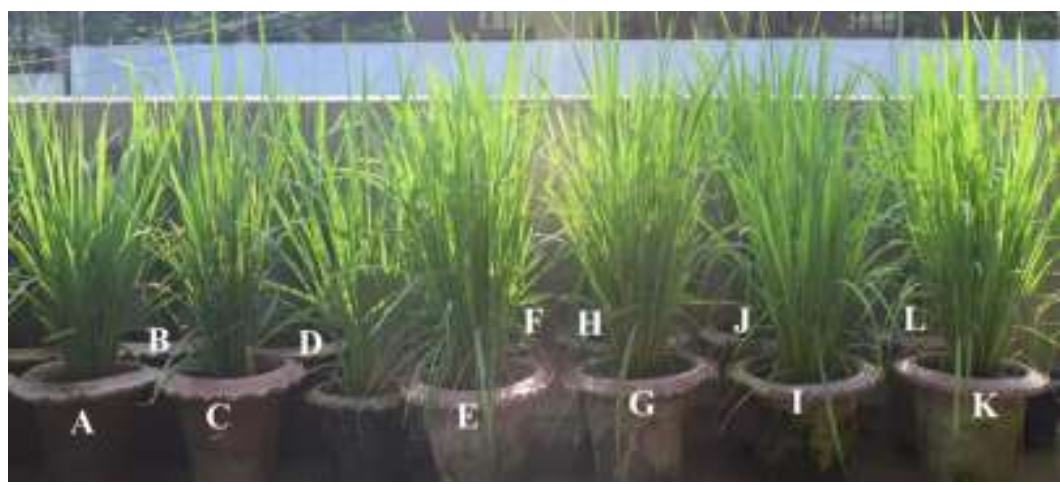

Fig. 6: Acclimatization of regenerated plantlets (A) SAAT; (B) Talmugur, (C) Jamaibabu, (D) Casrail, (E) BRRI Dhan76, (F) BRRI Dhan71, (G) Jota Balam, (H) Naya Paijam, (I) Nimi Khanai, (J) BRRI Dhan52, (K) BRRI Dhan28 and (L) BRRI Dhan29 on soil containing pots

Table 1: Effect of different concentrations of 2,4-D (2,4-Dichlorophenoxyacetic acid) on Callus Induction Frequency (CIF) of 12 indica rice genotypes

\begin{tabular}{|c|c|c|c|c|c|c|c|c|c|c|c|c|c|c|c|c|c|c|}
\hline \multirow[b]{3}{*}{$\begin{array}{l}\text { Rice } \\
\text { genotypes }\end{array}$} & \multicolumn{18}{|c|}{ Concentration of 2,4-D (mg/l) } \\
\hline & \multicolumn{2}{|l|}{0} & \multicolumn{2}{|l|}{1} & \multicolumn{2}{|l|}{1.5} & \multicolumn{2}{|l|}{2} & \multicolumn{2}{|l|}{2.5} & \multicolumn{2}{|l|}{3.0} & \multicolumn{2}{|l|}{3.5} & \multicolumn{2}{|l|}{4} & \multicolumn{2}{|l|}{5} \\
\hline & $\begin{array}{l}\text { Mean } \\
\text { CIF(\%) }\end{array}$ & \pm STD & $\begin{array}{l}\text { Mean } \\
\text { CIF(\%) }\end{array}$ & \pm STD & $\begin{array}{l}\text { Mean } \\
\text { CIF(\%) }\end{array}$ & \pm STD & $\begin{array}{l}\text { Mean } \\
\text { CIF(\%) }\end{array}$ & $\pm \mathrm{STD}$ & $\begin{array}{l}\text { Mean } \\
\text { CIF(\%) }\end{array}$ & \pm STD & $\begin{array}{l}\text { Mean } \\
\text { CIF(\%) }\end{array}$ & \pm STD & $\begin{array}{l}\text { Mean } \\
\text { CIF(\%) }\end{array}$ & \pm STD & $\begin{array}{l}\text { Mean } \\
\text { CIF(\%) }\end{array}$ & \pm STD & $\begin{array}{l}\text { Mean } \\
\text { CIF(\%) }\end{array}$ & $\pm \mathrm{STD}$ \\
\hline Saat & $0^{\mathrm{e}}$ & \pm 0 & $22.22^{\mathrm{de}}$ & \pm 5.09 & $32.22^{\mathrm{cd}}$ & \pm 3.57 & $50.00^{\mathrm{bc}}$ & \pm 6.67 & $68.89^{\mathrm{ab}}$ & \pm 6.94 & $84.44^{\mathrm{a}}$ & \pm 5.09 & $81.11^{\mathrm{a}}$ & \pm 8.39 & $65.46^{\mathrm{ab}}$ & \pm 1.85 & $58.89^{\mathrm{acb}}$ & \pm 5.09 \\
\hline Talmugur & $0^{\mathrm{e}}$ & \pm 0 & $27.78^{\mathrm{db}}$ & \pm 10.18 & $41.11^{\mathrm{cdb}}$ & \pm 8.34 & $63.33^{\mathrm{abc}}$ & \pm 8.82 & $76.67^{\mathrm{a}}$ & \pm 6.67 & $74.45^{\mathrm{a}}$ & \pm 6.94 & $64.44^{\mathrm{abc}}$ & \pm 8.39 & $50.00^{\text {abcd }}$ & \pm 8.66 & $46.67^{\mathrm{bcd}}$ & \pm 7.64 \\
\hline Jamaibabu & $0^{\mathrm{e}}$ & \pm 0 & $24.44^{\text {bde }}$ & \pm 7.70 & $31.67^{\mathrm{bcd}}$ & \pm 12.51 & $48.89^{\mathrm{b}}$ & \pm 6.94 & $70.00^{\mathrm{ab}}$ & \pm 8.82 & $78.89^{\mathrm{a}}$ & \pm 5.09 & $64.45^{\mathrm{ab}}$ & \pm 6.94 & $56.67^{\mathrm{abc}}$ & \pm 8.82 & $52.22^{\mathrm{abc}}$ & \pm 8.39 \\
\hline Casrial & $0^{\mathrm{d}}$ & \pm 0 & $21.67^{\mathrm{cd}}$ & \pm 7.64 & $43.33^{\mathrm{bc}}$ & \pm 10.05 & $53.33^{\mathrm{ab}}$ & \pm 6.67 & $73.33^{\mathrm{a}}$ & \pm 8.82 & $74.45^{\mathrm{a}}$ & \pm 6.94 & $70.00^{\mathrm{ab}}$ & \pm 8.82 & $60.00^{\mathrm{ab}}$ & \pm 10.00 & $56.67^{\mathrm{a}}$ & \pm 8.82 \\
\hline BRRI Dhan76 & $0^{\mathrm{e}}$ & \pm 0 & $23.33^{\mathrm{de}}$ & \pm 10.41 & $38.33^{\mathrm{c}}$ & \pm 3.85 & $54.44^{\text {ac }}$ & \pm 5.09 & $70.00^{\mathrm{ab}}$ & \pm 6.67 & $77.78^{\mathrm{a}}$ & \pm 12.62 & $60.00^{\mathrm{abc}}$ & \pm 10.00 & $52.22^{\mathrm{abc}}$ & \pm 6.94 & $45.56^{\mathrm{bcd}}$ & \pm 11.71 \\
\hline BRRI Dhan71 & $0^{\mathrm{c}}$ & \pm 0 & $35.00^{\mathrm{b}}$ & \pm 8.66 & $53.33^{\mathrm{a}}$ & \pm 10.05 & $62.22^{\mathrm{ab}}$ & \pm 6.94 & $78.89^{\mathrm{a}}$ & \pm 11.70 & $73.33^{\mathrm{a}}$ & \pm 10.00 & $70.00^{\mathrm{a}}$ & \pm 10.00 & $54.44^{\mathrm{ab}}$ & \pm 8.39 & $53.33^{\mathrm{ab}}$ & \pm 8.82 \\
\hline Jotabalam & $0^{\mathrm{b}}$ & \pm 0 & $51.67^{\mathrm{a}}$ & \pm 15.28 & $55.00^{\mathrm{a}}$ & \pm 12.58 & $56.67^{\mathrm{a}}$ & \pm 3.34 & $72.22^{\mathrm{a}}$ & \pm 8.39 & $63.33^{\mathrm{a}}$ & \pm 11.55 & $52.22^{\mathrm{a}}$ & \pm 5.09 & $50.00^{\mathrm{a}}$ & \pm 6.67 & $50.00^{\mathrm{a}}$ & \pm 14.53 \\
\hline Nayapaijam & $0^{\mathrm{c}}$ & \pm 0 & $41.67^{\mathrm{b}}$ & \pm 15.28 & $50.00^{\mathrm{ab}}$ & \pm 15.00 & $61.11^{\mathrm{ab}}$ & \pm 8.39 & $70.00^{\mathrm{a}}$ & \pm 8.82 & $72.22^{\mathrm{a}}$ & \pm 10.18 & $68.89^{\mathrm{a}}$ & \pm 7.70 & $52.22^{\mathrm{ab}}$ & \pm 1.92 & $45.56^{\mathrm{ab}}$ & \pm 8.39 \\
\hline Nimikhanai & $0^{\mathrm{f}}$ & \pm 0 & $25.00^{\text {def }}$ & \pm 10.00 & $51.67^{\mathrm{be}}$ & \pm 12.51 & $62.22^{\text {abcd }}$ & \pm 8.39 & $72.22^{\mathrm{abc}}$ & \pm 11.70 & $80.00^{\mathrm{ac}}$ & \pm 10.00 & $60.00^{\text {abcd }}$ & \pm 10.00 & $50.00^{\text {bce }}$ & \pm 8.82 & $44.44^{\text {bcd }}$ & \pm 9.62 \\
\hline BRRI Dhan52 & $0^{\mathrm{e}}$ & \pm 0 & $43.33^{\mathrm{d}}$ & \pm 5.77 & $48.33^{\text {bcd }}$ & \pm 8.22 & $52.22^{\mathrm{abcd}}$ & \pm 6.94 & $76.67^{\mathrm{a}}$ & \pm 12.02 & $65.56^{\text {abd }}$ & \pm 5.09 & $64.44^{\text {abcd }}$ & \pm 15.03 & $56.67^{\text {abcd }}$ & \pm 12.58 & $38.33^{\text {cd }}$ & \pm 5.77 \\
\hline BRRI Dhab28 & $0^{\mathrm{e}}$ & \pm 0 & $40.00^{\mathrm{bc}}$ & \pm 5.00 & $51.67^{\mathrm{abc}}$ & \pm 10.05 & $55.56^{\mathrm{abc}}$ & \pm 8.39 & $62.22^{\mathrm{ac}}$ & \pm 6.94 & $68.89^{\mathrm{a}}$ & \pm 7.70 & $50.00^{\mathrm{abc}}$ & \pm 6.67 & $43.33^{\mathrm{abc}}$ & \pm 10.41 & $38.33^{\mathrm{c}}$ & \pm 7.64 \\
\hline BRRI Dhan29 & $0^{\mathrm{c}}$ & \pm 0 & $18.33^{\mathrm{bc}}$ & \pm 2.89 & $45.00^{\mathrm{ab}}$ & \pm 2.89 & $53.33^{\mathrm{a}}$ & \pm 5.77 & $70.00^{\mathrm{a}}$ & \pm 6.67 & $61.11^{\mathrm{a}}$ & \pm 8.39 & $56.67^{\mathrm{a}}$ & \pm 8.82 & $47.78^{\mathrm{a}}$ & \pm 5.09 & $50.00^{\mathrm{a}}$ & \pm 5.77 \\
\hline
\end{tabular}
other at $5 \%$ significance level. \pm STD $=$ standard deviatio

Table 2: Effect of different concentrations of concentration of BA+ NAA in N6 medium on Shoot Induction Frequency (SIF) of 12 indica rice genotypes Concentration of BA+NAA (mg/l)

\begin{tabular}{|c|c|c|c|c|c|c|c|c|c|c|c|c|c|c|}
\hline \multirow[b]{2}{*}{ Rice genotypes } & \multicolumn{2}{|l|}{$0+0$} & \multicolumn{2}{|l|}{$1.0+0.5$} & \multicolumn{2}{|l|}{$1.5+1.0$} & \multicolumn{2}{|l|}{$2.0+1.0$} & \multicolumn{2}{|l|}{$2.5+1.0$} & \multicolumn{2}{|l|}{$3.0+1.5$} & \multicolumn{2}{|l|}{$3.5+1.5$} \\
\hline & $\begin{array}{l}\text { Mean } \\
\text { SIF(\%) }\end{array}$ & \pm STD & $\begin{array}{l}\text { Mean } \\
\text { SIF(\%) }\end{array}$ & \pm STD & $\begin{array}{l}\text { Mean } \\
\text { SIF(\%) }\end{array}$ & \pm STD & $\begin{array}{l}\text { Mean } \\
\text { SIF(\%) }\end{array}$ & \pm STD & $\begin{array}{l}\text { Mean } \\
\text { SIF(\%) }\end{array}$ & \pm STD & $\begin{array}{l}\text { Mean } \\
\text { SIF(\%) }\end{array}$ & \pm STD & $\begin{array}{l}\text { Mean } \\
\text { SIF(\%) }\end{array}$ & \pm STD \\
\hline Saat & $0.00^{\mathrm{d}}$ & \pm 0.00 & $26.67^{c}$ & \pm 12.58 & $36.67^{\mathrm{bc}}$ & \pm 16.07 & $58.33^{\mathrm{ab}}$ & \pm 10.41 & $75.00^{\mathrm{ab}}$ & \pm 8.66 & $80.00^{\mathrm{a}}$ & \pm 10.00 & $61.67^{\mathrm{ab}}$ & \pm 12.58 \\
\hline Talmugur & $0.00^{\mathrm{d}}$ & \pm 0.00 & $20.00^{\mathrm{cd}}$ & \pm 8.66 & $36.67^{\mathrm{bc}}$ & \pm 10.41 & $65.00^{\mathrm{a}}$ & \pm 13.23 & $75.00^{\mathrm{a}}$ & \pm 10.00 & $80.00^{\mathrm{a}}$ & \pm 5.00 & $73.33^{\mathrm{a}}$ & \pm 7.64 \\
\hline Jamaibabu & $0.00^{\mathrm{d}}$ & \pm 0.00 & $30.00^{\mathrm{c}}$ & \pm 13.23 & $43.33^{\mathrm{bc}}$ & \pm 5.77 & $63.33^{\mathrm{ab}}$ & \pm 5.77 & $83.33^{\mathrm{a}}$ & \pm 7.64 & $81.67^{\mathrm{a}}$ & \pm 7.64 & $66.67^{\mathrm{ab}}$ & \pm 2.89 \\
\hline Casrial & $0.00^{\mathrm{e}}$ & \pm 0.00 & $18.33^{\mathrm{de}}$ & \pm 10.41 & $46.67^{\mathrm{c}}$ & \pm 7.64 & $71.67^{\mathrm{abc}}$ & \pm 7.64 & $80.00^{\mathrm{a}}$ & \pm 5.00 & $71.67^{\mathrm{abc}}$ & \pm 10.41 & $53.33^{\mathrm{bc}}$ & \pm 15.28 \\
\hline BRRI Dhan76 & $0.00^{\mathrm{e}}$ & \pm 0.00 & $26.67^{\mathrm{e}}$ & \pm 12.58 & $43.33^{\mathrm{cd}}$ & \pm 5.77 & $48.33^{\text {bcd }}$ & \pm 7.64 & $76.67^{\mathrm{a}}$ & \pm 10.41 & $81.67^{\mathrm{a}}$ & \pm 7.64 & $68.33^{\mathrm{abc}}$ & \pm 7.64 \\
\hline BRRI Dhan71 & $0.00^{\mathrm{d}}$ & \pm 0.00 & $23.33^{\mathrm{cd}}$ & \pm 10.41 & $46.67^{\mathrm{bc}}$ & \pm 7.64 & $61.67^{\mathrm{ab}}$ & \pm 7.64 & $86.67^{\mathrm{a}}$ & \pm 2.89 & $73.33^{\mathrm{ab}}$ & \pm 7.64 & $60.00^{\mathrm{ab}}$ & \pm 10.00 \\
\hline Jotabalam & $0.00^{\mathrm{d}}$ & \pm 0.00 & $18.33^{\text {cd }}$ & \pm 5.77 & $43.33^{\mathrm{bc}}$ & \pm 5.77 & $61.67^{\mathrm{ab}}$ & \pm 11.55 & $80.00^{\mathrm{a}}$ & \pm 10.00 & $75.00^{\mathrm{a}}$ & \pm 8.66 & $66.67^{\mathrm{ab}}$ & \pm 11.55 \\
\hline Nayapaijam & $0.00^{\mathrm{d}}$ & \pm 0.00 & $16.67^{\mathrm{cd}}$ & \pm 2.89 & $46.67^{b}$ & \pm 10.41 & $78.33^{\mathrm{a}}$ & \pm 7.64 & $85.00^{\mathrm{a}}$ & \pm 8.66 & $76.67^{\mathrm{a}}$ & \pm 10.41 & $68.33^{\mathrm{ab}}$ & \pm 7.64 \\
\hline Nimikhanai & $0.00^{\mathrm{e}}$ & \pm 0.00 & $21.67^{\mathrm{de}}$ & \pm 7.64 & $36.67^{\mathrm{cd}}$ & \pm 7.64 & $53.33^{\mathrm{bc}}$ & \pm 12.58 & $73.33^{\mathrm{ab}}$ & \pm 7.64 & $86.67^{\mathrm{a}}$ & \pm 5.77 & $71.67^{\mathrm{ab}}$ & \pm 7.64 \\
\hline BRRI Dhan52 & $0.00^{\mathrm{f}}$ & \pm 0.00 & $18.33^{\text {ef }}$ & \pm 10.41 & $40.00^{\mathrm{de}}$ & \pm 10.00 & $55.00^{\mathrm{bcd}}$ & \pm 10.00 & $83.33^{\mathrm{a}}$ & \pm 7.64 & $78.33^{\mathrm{abc}}$ & \pm 2.89 & $53.33^{\mathrm{cd}}$ & \pm 10.41 \\
\hline BRRI Dhab28 & $0.00^{\mathrm{e}}$ & \pm 0.00 & $23.33^{\mathrm{de}}$ & \pm 10.41 & $43.33^{\text {cd }}$ & \pm 2.89 & $61.67^{\mathrm{bc}}$ & \pm 7.64 & $81.67^{\mathrm{ab}}$ & \pm 2.89 & $88.33^{\mathrm{a}}$ & \pm 7.64 & $73.33^{\mathrm{ab}}$ & \pm 11.55 \\
\hline BRRI Dhan29 & $0.00^{\mathrm{d}}$ & \pm 0.00 & $28.33^{\mathrm{c}}$ & \pm 10.41 & $48.33^{\mathrm{bc}}$ & \pm 7.64 & $58.33^{\mathrm{ab}}$ & \pm 2.89 & $78.33^{\mathrm{a}}$ & \pm 10.41 & $83.33^{\mathrm{a}}$ & \pm 5.77 & $66.67^{\mathrm{ab}}$ & \pm 7.64 \\
\hline
\end{tabular}

*Different lowercase letters represent significant difference between means due to different concentrations of BA+NAA. Treatment groups with at least one common letter are not significantly different from each other at $5 \%$ significance level. \pm STD $=$ standard deviation

\section{Discussion}

2,4-D is one of the important synthetic auxins which is extensively used in tissue culture for callus induction (Zhu et al., 1996; Sankepally and Singh, 2016). Many reports suggest that media supplemented 2,4-D along with BA (Sahoo et al., 2011) or NAA (Bano et al., 2005) give better callus induction rate. But in this study, we only used 2,4-D for callus induction of 12 indica rice genotypes and found better callus induction frequencies (up to 84\%) compared to other reports (Tariq et al., 2008; Khan, 2019). The colour of most of the calli was light yellowish, which is the feature of the good and reproducible callus. The calli were also found compact and globular in structure whichis also a feature of good quality callus (Ahmad et al., 2016). 2,4-D is also one of the most extensively used synthetic herbicides to control broadleaf weeds by causing uncontrolled growth (Haupt et al., 1998). So high concentration of 2, 4-D had a negative impact on the callus and inhibit shoot induction from calli 
(Rai and Pandey-Rai, 2014). In this study, the maximum concentration of 2,4-D used was $5 \mathrm{mg} / \mathrm{l}$. The data analysis of callus induction showed that below $2 \mathrm{mg} / \mathrm{l} 2,4-\mathrm{D}$ give rise to a lower number of callus, and supplementation of 2.5-3.5 mg/1 2,4-D results in a relatively high amount of callus. Among these 2,4-D concentrations, $3 \mathrm{mg} / \mathrm{l}$ showed the best callus induction frequencies, which are supported by many reports (Tariq et al., 2008). Increment of 2, 4-D concentration above $3.5 \mathrm{mg} / \mathrm{l}$ givesa lower number of callus and callus induction frequency gradually decrease by the increment of 2,4-D concentration. Shoot induction from callus is one of the crucial steps of tissue cultures and is entirely dependent on callus type and PGR supplementation. Many reports suggest that media supplemented with the proper concentration of BA give a good number of shoots, but suitable concentrations of BA varies from genotypes to genotypes (Patel et al., 2018; Sama et al., 2012). In this study, we used a comparatively high concentration of BA alongwith a low concentration of NAAbecause many reports suggested that without supplementation of NAA give rise to weak plantlets (Zuraida et al., 2010; Rueb et al., 1994). Data analysis showed that low concentration of BA and NAA give lower shooting frequency, and shoot induction frequency increased with the increment of BA and NAA concentration. But shoot induction frequency decreased with the supplementation of high concentration of BA and NAA (above $3.0 \mathrm{mg} / \mathrm{l} \mathrm{BA}+1.5 \mathrm{mg} / \mathrm{l} \mathrm{NAA}$ ), which is supported by previous reports (Sankepally and Singh, 2016; Tariq et al., 2008). Successful plant regeneration entirely depends on high numbers of root induction. Previous reports suggest that an adequate number of roots are induced on the MS media supplemented with Indole-3-Butyric Acid (IBA) or Indoleacetic Acid (IAA). In this study, we did not use any hormone for root induction and for root induction, the plantlets were inoculated on half-strength MS media, which resulted in the formation of enough roots within two weeks (Kumar et al., 2012). The plantlets with roots were washed with normal water to remove the media and were transplanted in soil containing pots. After one week of transplantation, plantlets started vegetative growth, and after 4/5 weeks, plants showed remarkable growth performance.

\section{Conclusion}

In this study, in-vitro callus induction and regeneration of twelve indica rice genotypes were studied. Suitable basal media and plant growth regulators for the selected rice genotypes were investigated for improving callus and regeneration frequency. Although fungal contamination is the major problem in tissue culture, it can be minimized with extracarefulness. All chemicals, glassware and media should be properly sterilized, and the workbench (laminar airflow cabinet) should be clean and made contaminant free.It was observed that the selected rice genotypes showed better callus induction on the Chu's N6 media than MS or Gamborg's B5 media. Appropriate concentration $(2.5 \mathrm{mg} / \mathrm{l}-$
$3.0 \mathrm{mg} / \mathrm{l})$ of 2,4-D significantly increased the callus induction frequency and correct combination $(2.5+1.5$ and 3.0+1.5 $\mathrm{mg} / \mathrm{l}$ ) of BA and NAArespectively provided increased shoot induction frequency. Compared with previous studies, we can conclude that there is no significant impact of PGRs on the rooting of the selected rice genotypes because we observeda significant amount of roots without any supplementation of the hormones. Thus, this investigation showed an efficient regeneration system for the selected indica rice genotypes which will provide the opportunity for further research in the genetic transformation and CRISPR-Cas 9 mediated genome modification in indica rice.

\section{Acknowledgement}

The authors are grateful to the Plant Genetic Engineering Lab, Department of Genetic Engineering and Biotechnology, Shahjalal University of Science and Technology, Sylhet. The authors are also thankful to the United States Department of Agriculture (USDA) for financial support to conduct this research.

\section{Author Contributions}

Md. Nazmul Hasan: Conceptualization, data curation, methodology and writing original draft.

Fahmid H. Bhuiyan: Data curation, methodology and writing original draft.

Hammadul Hoque: Formal analysis, review and editing.

Nurnabi Azad Jewel: Investigation, review and editing.

Md. Ashrafuzzaman: Formal analysis, investigation.

Shamsul H. Prodhan: Supervision, validation, review and editing.

\section{Conflict of Interest}

This article is original and contains unpublished materials. Shamsul H. Prodhan, the corresponding author, confirms that all the authors have read and approved the manuscript.

\section{References}

Ahmad, F. I., Wagiran, A., AbdSamad, A., Rahmat, Z., \&Sarmidi, M. R. (2016). Improvement of efficient in vitro regeneration potential of mature callus induced from Malaysian upland rice seed (Oryza sativa cv. Panderas). Saudi Journal of Biological Sciences, 23(1), S69-S77. https://doi.org/10.1016/j.sjbs.2015.10.022

Bano, S., Jabeen, M., Rahim, F., \& Ilahi, I. (2005). Callus induction and regeneration in seed explants of rice (Oryza sativa cv. Swat-II. Pakistan Journal of Botany, $37(4)$,

829.https://www.pakbs.org/pjbot/PDFs/37(4)/PJB37(4 )0829.pdf 
Bello, M. A., Ruiz-León, Y., Sandoval-Sierra, J. V., Rezinciuc, S., \& Diéguez-Uribeondo, J. (2017). Scanning electron microscopy (SEM) protocols for problematic plant, oomycete and fungal samples. Journal of visualized experiments: JoVE, (120).https://www.ncbi.nlm.nih.gov/pmc/articles/P MC5408598/

Benderradji, L., Brini, F., Kellou, K., Ykhlef, N., Djekoun, A., Masmoudi, K., \&Bouzerzour, H. (2012). Callus induction, proliferation and plantlets regeneration of two bread wheat (Triticumaestivum L.) genotypes under saline and heat stress conditions. International Scholarly Research Notices, 2012. https://doi.org/10.5402/2012/367851

BinteMostafiz, S., \&Wagiran, A. (2018). Efficient callus induction and regeneration in selected indica rice. Agronomy, $8(5)$, 77 https://doi.org/10.3390/agronomy8050077

Chakraborty, A., Hoque, H., Hasan, M. N., Akter, F., Suhani, S., Joy, Z. F., \&Akther, J. (2017). Effect of Different Concentrations of Plant Growth Hormones for in Vitro Regeneration of Rice Varieties BRRI Dhan28 and BRRI Dhan29. International Journal of Sciences: Basic and Applied Research, 33(2), 26-33.

Das, N. K., Hoque, H., Hasan, M. N., \& Prodhan, S. H. (2019). Research Article Effect of Plant Growth Regulators and Proline in Efficient Regeneration of Recalcitrant Indica Rice (Oryza sativa L.).https://www.scialert.net/abstract/?doi=jbs.201 9.290.299

Gnanamanickam, S. S. (2009). Rice and its importance to human life. In Biological control of rice diseases (pp. 1-11). Springer, Dordrecht.https://link.springer.com/chapter/10.1007/ 978-90-481-2465-7_1

Hasan, M. N., Hasan, M. R., Foysal, S. H., Hoque, H., Khan, M. F., Bhuiyan, M. F. H., \& Prodhan, S. H. (2019a). In-vitro regeneration of Citrus sinensis (L.) Osbeck from mature seed derived embryogenic callus on different solid basal media. American Journal of Plant Sciences, 10(2), 285-297. https://doi.org/10.4236/ajps.2019.102022

Hasan, N., Kamruzzaman, M., Islam, S., Hoque, H., Bhuiyan, F. H., \& Prodhan, S. H. (2019b). Development of partial abiotic stress tolerant Citrus reticulata Blanco and Citrus sinensis (L.) Osbeck through Agrobacterium-mediated transformation method. Journal of Genetic Engineering and Biotechnology, 17(1), 1-9. https://doi.org/10.1186/s43141-019-0014-3

Haupt, K., Dzgoev, A., \& Mosbach, K. (1998). Assay system for the herbicide 2, 4-dichlorophenoxyacetic acid using a molecularly imprinted polymer as an artificial recognition element. Analytical chemistry, $70(3)$,

628-631.

https://pubs.acs.org/doi/abs/10.1021/ac9711549
Hiei, Y., \& Komari, T. (2008). Agrobacterium-mediated transformation of rice using immature embryos or calli induced from mature seed. Nature protocols, 3(5), 824-834. https://doi.org/10.1038/nprot.2008.46

Islam, M. Z., Khalequzzaman, M., Prince, M. F. R. K., Siddique, M. A., Rashid, E. S. M. H., Ahmed, M. S. U., ... \& Ali, M. P. (2018). Diversity and population structure of red rice germplasm in Bangladesh. PLoS One, 13(5), e0196096. https://doi.org/10.1371/journal.pone.0196096

Khan, M. N. M. (2019). In vitro Callus induction of aromatic rice depends on the concentration of 2, 4-D. Malaysian Journal of Halal Research, 2(2), 9-13. https://doi.org/10.2478/mjhr-2019-0007

Kromdijk, J., \& Long, S. P. (2016). One crop breeding cycle from starvation? How engineering crop photosynthesis for rising $\mathrm{CO} 2$ and temperature could be one important route to alleviation. Proceedings of the Royal Society B: Biological Sciences, 283(1826), 20152578. http://doi.org/10.1098/rspb.2015.2578

Kumar, S. R., Krishna, V., Pradeepa, K., Kumar, K. G., \&Gnanesh, A. U. (2012). Direct and indirect method of plant regeneration from root explants of Caesalpiniabonduc (L.) Roxb.-A threatened medicinal plant of Western Ghats.http://nopr.niscair.res.in/handle/123456789/ 15179

Linares, O. F. (2002). African rice (Oryzaglaberrima): history and future potential. Proceedings of the National Academy of Sciences, 99(25), 16360-16365. https://doi.org/10.1073/pnas.252604599

Mazumdar, S., Quick, W. P., \&Bandyopadhyay, A. (2016). CRISPR-Cas9 mediated genome editing in rice, advancements and future possibilities. Indian Journal of Plant Physiology, 21(4), 437-445. https://doi.org/10.1007/s40502-016-0252-1

Mazumder, S. R., Hoque, H., Sinha, B., Chowdhury, W. R., Hasan, M. N., \& Prodhan, S. H. (2020). Genetic variability analysis of partially salt tolerant local and inbred rice (Oryza sativa L.) through molecular markers. Heliyon, 6(8), e04333. https://doi.org/10.1016/j.heliyon.2020.e04333

Miyao, A., Nakagome, M., Ohnuma, T., Yamagata, H., Kanamori, H., Katayose, Y., ... \&Hirochika, H. (2012). Molecular spectrum of somaclonal variation in regenerated rice revealed by wholegenome sequencing. Plant and Cell Physiology, 53(1), 256-264. https://doi.org/10.1093/pcp/pcr172

Mukherjee, A., Islam, M. R., Nasiruddin, K. M., \& Banerjee, P. (2015). Study on callus initiation and plantlet regeneration ability of some rice genotypes. International Journal Science TechnologyResearch, 4 ; 354-61. 
Ngomuo, M., Mneney, E., \& Ndakidemi, P. (2013). The effects of auxins and cytokinin on growth and development of (Musa sp.) var."Yangambi" explants in tissue culture. American Journal of Plant Sciences, $4(11)$, 2174. http://dx.doi.org/10.4236/ajps.2013.411269

Nic-Can, G., Hernández-Castellano, S., Kú-González, A., Loyola-Vargas, V. M., \& De-la-Peña, C. (2013). An efficient immunodetection method for histone modifications in plants. Plant Methods, 9(1), 1-9. https://doi.org/10.1186/1746-4811-9-47

Pasqualetto, P. L. (1990). Factors Affecting Tissue Culture Success in Mass Propagation. In Plant Aging (pp. 75-80). Springer, Boston, MA. https://doi.org/10.1007/978-1-4684-5760-5_9

Patel, A., Singh, P., \& Khan, S. (2018). Standardization of Protocol for in vitroMicropropagation of Phyllanthusniruri: An Important Medicinal Plant. UKJPB. 6(4); 42-47. http://dx.doi.org/10.20510/ukjpb/6/i4/177339

Paul, S., \& Roychoudhury, A. (2019). Comparative Analyses of Regeneration Potentiality of Eight Indigenous Aromatic Indica rice (Oryza sativa L.) Varieties. Int. J. Sci. Res. in Biological Sciences Vol, 6, 1. https://doi.org/10.26438/ijsrbs/v6i1.5564

Phillips, G. C., \& Garda, M. (2019). Plant tissue culture media and practices: an overview. In Vitro Cellular \& Developmental https://doi.org/10.1007/s11627-019-09983-5

Rai, K. K., \& Pandey-Rai, S. (2014). Effect of 2, 4-D on phenolics production and detection of in vitro culture-induced variation through inter-simple sequence repeat and RAPD analysis in Artemisia annua L. International Journal of Pharma and Bio Sciences, $5(2)$. https://www.cabdirect.org/cabdirect/abstract/2014 3288260

Rasheed, R., Ashraf, M. A., Iqbal, M., Hussain, I., Akbar, A., Farooq, U., \& Shad, M. I. (2020). Major Constraints for Global Rice Production: Changing Climate, Abiotic and Biotic Stresses. In Rice Research for Quality Improvement: Genomics and Genetic Engineering (pp. 15-45). Springer, Singapore. https://doi.org/10.1007/978-9\81-15-4120-9_2

Romero, F. M., \&Gatica-Arias, A. (2019). CRISPR/Cas9: development and application in rice breeding. Rice Science, 26(5), 265-281. https://www.sciencedirect.com/science/article/pii/S1 672630819300599

Rueb, S., Leneman, M., Schilperoort, R. A., \&Hensgens, L. A. M. (1994). Efficient plant regeneration through somatic embryogenesis from callus induced on mature rice embryos (Oryza sativa L.). Plant Cell, Tissue and Organ Culture, 36(2), 259-264. https://link.springer.com/article/10.1007/BF00037729
Sahoo, K. K., Tripathi, A. K., Pareek, A., Sopory, S. K., \& Singla-Pareek, S. L. (2011). An improved protocol for efficient transformation and regeneration of diverse indica rice cultivars. Plant Methods, 7(1), 1-11. https://doi.org/10.1186/17464811-7-49

Sama, A. E., Hughes, H. G., Abbas, M. S., \&Shahba, M. A. (2012). An efficient in vitro propagation protocol of cocoyam [Xanthosomasagittifolium (L) Schott]. The Scientific World Journal, 2012. https://doi.org/10.1100/2012/346595

Sankepally, S. S. R., \& Singh, B. (2016). Optimization of regeneration using differential growth regulators in indica rice cultivars. 3 Biotech, 6(1), 19. https://doi.org/10.1007/s13205-015-0343-0

Sen, M. K., Nasrin, S., Rahman, S., \& Jamal, A. H. M. (2014). In vitro callus induction and plantlet regeneration of Achyranthesaspera L., a high value medicinal plant. Asian Pacific Journal of Tropical Biomedicine, 4(1), 40-46. https://doi.org/10.1016/S2221-1691(14)60206-9

Tariq, M., Ali, G., Hadi, F., Ahmad, S., Ali, N., \& Shah, A. A. (2008). Callus Induction and in vitro Plant Regeneration of Rice (Oryza sativa L.). Pakistan Journal of Biological Sciences, 11(2); 255-259.

Wright, S. (2020). Largest Rice-Producing Countries. WorldAtlas. https://www.worldatlas.com/articles/largest-riceproducing-countries.html

Yaqoob, U., Jan, B., Kaul, T., \& Nawchoo, I. A. (2016). Tissue culture of rice: Problems, progress and prospects. International Journal of Innovative Science, Engineering and Technology, 3(6), 581-613. http://ijiset.com/vol3/v3s6/IJISET_V3_I6_78.pdf

Zahara, M., Datta, A., Boonkorkaew, P., \& Mishra, A. (2017). The effects of different media, sucrose concentrations and natural additives on plantlet growth of Phalaenopsishybrid'Pink'. Brazilian Archives of Biology and Technology, 60. http://dx.doi.org/10.1590/1678-4324-2017160149

Zhu, Y., Ouyang, W., Li, Y., \& Chen, Z. (1996). The effects of 2ip and 2, 4-D on rice calli differentiation. Plant Growth Regulation, 19(1), 19-24. https://doi.org/10.1007/BF00024398

Zuraida, A. R., Suri, R., Wan, Z., \& Sreeramanan, S. (2010). Regeneration of Malaysian indica rice (Oryza sativa) variety MR232 via optimised somatic embryogenesis system. Journal of Phytology, 2(3), 30-38 https://www.cabdirect.org/cabdirect/abstract/2011 3034560 
Md. Nazmul Hasan et al. / American Journal of Biochemistry and Biotechnology 2021, 17 (2): 148.159 DOI: 10.3844/ajbbsp.2021.148.159

\section{Supplementary}

Table 1: Shoot number, shoot length, root number and root length of regenerated plantlets

\begin{tabular}{|c|c|c|c|c|c|c|c|c|c|c|c|c|c|c|c|c|c|c|c|c|}
\hline \multirow{2}{*}{$\begin{array}{l}\text { Rice } \\
\text { Genotypes }\end{array}$} & \multicolumn{3}{|c|}{ Shoot number } & \multirow[b]{2}{*}{ Mean } & \multirow[b]{2}{*}{ \pm STD } & \multicolumn{5}{|c|}{ Shoot Length $(\mathrm{cm})$} & \multicolumn{3}{|c|}{ Root Number } & \multirow[b]{2}{*}{ Mean } & \multirow[b]{2}{*}{ \pm STD } & \multicolumn{3}{|c|}{ Root length (cm) } & \multirow[b]{2}{*}{ Mean } & \multirow[b]{2}{*}{ \pm STD } \\
\hline & 1 & 2 & 3 & & & 1 & 2 & 3 & Mean & \pm STD & 1 & 2 & 3 & & & 1 & 2 & 3 & & \\
\hline Saat & 9 & 12 & 7 & 9.33 & 2.52 & 15 & 8 & 14 & 12.33 & 3.79 & 15 & 18 & 13 & 15.33 & 2.52 & 2.3 & 2.6 & 2.8 & 2.57 & 0.25 \\
\hline Talmugur & 7 & 11 & 8 & 8.67 & 2.08 & 18 & 23 & 20 & 20.33 & 2.52 & 11 & 8 & 14 & 11.00 & 3.00 & 3 & 2.1 & 2.5 & 2.53 & 0.45 \\
\hline Jamaibabu & 12 & 7 & 9 & 9.33 & 2.52 & 25 & 23 & 25 & 24.33 & 1.15 & 15 & 12 & 8 & 11.67 & 3.51 &. .2 & 2.5 & 2.8 & 2.65 & 1.54 \\
\hline Casrial & 9 & 4 & 7 & 6.67 & 2.52 & 23 & 20 & 18 & 20.33 & 2.52 & 12 & 16 & 15 & 14.33 & 2.08 & 2.8 & 2.3 & 3 & 2.70 & 0.36 \\
\hline BRRI Dhan76 & 8 & 11 & 9 & 9.33 & 1.53 & 18 & 19 & 23 & 20.00 & 2.65 & 8 & 9 & 11 & 9.33 & 1.53 & 2.9 & 2.9 & 2.5 & 2.77 & 0.23 \\
\hline BRRI Dhan71 & 8 & 6 & 5 & 6.33 & 1.53 & 22 & 24 & 26 & 24.00 & 2.00 & 14 & 10 & 12 & 12.00 & 2.00 & 2.1 & 2.5 & 2 & 2.20 & 0.26 \\
\hline Jotabalam & 8 & 23 & 9 & 13.33 & 8.39 & 15 & 17 & 15 & 15.67 & 1.15 & 16 & 14 & 10 & 13.33 & 3.06 & 2.6 & 2.6 & 2.3 & 2.50 & 0.17 \\
\hline Nayapaijam & 4 & 7 & 6 & 5.67 & 1.53 & 22 & 25 & 18 & 21.67 & 3.51 & 11 & 15 & 15 & 13.67 & 2.31 & 2.3 & 2 & 2.5 & 2.27 & 0.25 \\
\hline Nimikhanai & 12 & 6 & 8 & 8.67 & 3.06 & 25 & 24 & 20 & 23.00 & 2.65 & 16 & 17 & 17 & 16.67 & 0.58 & 2.4 & 2.3 & 2.6 & 2.43 & 0.15 \\
\hline BRRI Dhan52 & 13 & 10 & 8 & 10.33 & 2.52 & 20 & 14 & 15 & 16.33 & 3.21 & 9 & 16 & 13 & 12.67 & 3.51 & 2.1 & 2.4 & 3 & 2.50 & 0.46 \\
\hline BRRI Dhab28 & 3 & 8 & 5 & 5.33 & 2.52 & 25 & 29 & 26 & 26.67 & 2.08 & 13 & 14 & 20 & 15.67 & 3.79 & 2.3 & 2.7 & 3.2 & 2.73 & 0.45 \\
\hline BRRI Dhan29 & 6 & 10 & 7 & 7.67 & 2.08 & 23 & 19 & 23 & 21.67 & 2.31 & 12 & 8 & 11 & 10.33 & 2.08 & 2.6 & 2.6 & 1.8 & 2.33 & 0.46 \\
\hline & & & & 8.39 & 2.25 & & & & 20.53 & 4.06 & & & & 13.00 & 2.25 & & & & 2.52 & 0.17 \\
\hline
\end{tabular}

Table 2: Tiller number and length of acclimatized plantlets

\begin{tabular}{|c|c|c|c|c|c|c|c|c|c|c|}
\hline \multirow[b]{2}{*}{ Rice Genotypes } & \multicolumn{3}{|c|}{ Tiller number } & \multirow[b]{2}{*}{ Mean } & \multirow[b]{2}{*}{ \pm STD } & \multicolumn{3}{|c|}{ Tiller Length $(\mathrm{cm})$} & \multirow[b]{2}{*}{ Mean } & \multirow[b]{2}{*}{ \pm STD } \\
\hline & 1 & 2 & 3 & & & 1 & 2 & 3 & & \\
\hline Saat & 33 & 35 & 25 & 31.00 & 5.29 & 45 & 36 & 46 & 42.33 & 5.06 \\
\hline Jamaibabu & 25 & 35 & 19 & 26.33 & 8.08 & 45 & 52 & 56 & 51.00 & 2.65 \\
\hline Casrial & 35 & 23 & 28 & 28.67 & 6.03 & 46 & 54 & 56 & 52.00 & 2.00 \\
\hline BRRI Dhan76 & 21 & 28 & 24 & 24.33 & 3.51 & 51 & 51 & 47 & 49.67 & 2.04 \\
\hline BRRI Dhan71 & 25 & 31 & 30 & 28.67 & 3.21 & 49 & 61 & 48 & 52.67 & 6.59 \\
\hline Jotabalam & 29 & 18 & 29 & 25.33 & 6.35 & 45 & 47 & 43 & 45.00 & 2.00 \\
\hline Nayapaijam & 26 & 16 & 22 & 21.33 & 5.03 & 59 & 54 & 44 & 52.33 & 5.36 \\
\hline Nimikhanai & 18 & 17 & 28 & 21.00 & 6.08 & 54 & 53 & 51 & 52.67 & 1.07 \\
\hline BRRI Dhan52 & 16 & 22 & 26 & 21.33 & 5.03 & 62 & 61 & 60 & 61.00 & 0.58 \\
\hline BRRI Dhab28 & 13 & 23 & 24 & 20.00 & 6.08 & 48 & 58 & 53 & 53.00 & 2.89 \\
\hline \multirow[t]{2}{*}{ BRRI Dhan29 } & 21 & 25 & 29 & 25.00 & 4.00 & 53 & 49 & 50 & 50.67 & 0.84 \\
\hline & & & & 24.61 & 3.55 & & & & 51.67 & 4.90 \\
\hline
\end{tabular}

Table 3: Impact of light condition in callus induction on different basal medium

\begin{tabular}{llllll}
\hline & Dark Condition & & \multicolumn{2}{l}{ Light Condition } \\
Medium & Mean (\%) & SD & SEM & Mean (\%) & SD \\
\hline MS & 83.13 & 4.43 & 3.13 & 80.29 & 0.79 \\
N6 & 90.21 & 1.25 & 0.88 & 86.33 & 2.43 \\
B5 & 75.63 & 2.75 & 1.95 & 70.83 & 5.14 \\
\hline
\end{tabular}

